\title{
Norms, Values and Cynical Games with Party Ideology
}

\author{
BØRGE BAKKEN
}

\begin{abstract}
The Chinese Communist Party is based on an ideology that was once fundamentally linked to social norms and values. The original charisma of the party and its leaders seems to have gone in the direction predicted by Max Weber: that charisma cannot stand the test of everyday routines; it will eventually be rationalized and bureaucratized. The party's slogan of 'three representations' seems to reach out to the 'new social strata,' allowing entry to those who 'became rich first,' namely the entrepreneurs. At the same time, the party struggles to redefine the Marxist paradigm of exploitation in a situation where workers increasingly live under conditions akin to those in England at the time of the Industrial Revolution. Sweeping changes are being implemented but without any modification to the verbal baggage of socialist propaganda.
\end{abstract}

\section{Losing the Mandate of History}

It has been argued that the 'mandate of Heaven' that represented legitimacy for the imperial dynasties was superseded by the Chinese Communist Party's 'mandate of history.' It is further posited that the CCP is vulnerable in the event that popular perception should deem that they have lost this authority. ${ }^{1}$ This paper will look at the ideology of the party, and raise the question whether the CCP is about to lose its mandate. It is possible that a bureaucratized party founded on an ideology that lacks any firm linkage to social norms and values, and divorced from any social movement, could be moving towards breakdown. The party is trying to renew and modernize itself, seeking new social moorings and support. It might succeed in reconstructing its 'mandate of history,' but there is a clear danger that it might lose its grip on the hearts and minds of the people.

Ideology is to a great extent linked to the image-making capacity of a power structure; indeed, it is a means of defending the prestige structure of a regime. Such a prestige structure depends on the creation and maintenance of an image that will inspire the admiration, fear, hopes and fortunes of its adherents. People must feel that the organization or 
party that carries this mandate is necessary for their own lives and fortunes. As pointed out by Mark Elvin: 'Once the image begins to suffer damage, little will happen for a while, but then a process of negative feedback develops, leading to a startlingly sudden collapse.' ${ }^{2}$ The rituals of ideology gain in significance viewed from this perspective. They bolster the façade of the party, and this is key to its success and survival, and its capacity to stay in power. However, there are both ideological and structural processes that have the potential to erode the power of the party. Subversive elements might threaten the party from the outside, but there is also a structural threat which comes from within.

The generation that grew up with the Chinese Communist Party, those who were young and malleable in the 1950s and 1960s, were fired by a communist ideology that enjoyed a moral power in some ways similar to that of the great religions of Christianity, Islam or Buddhism. We should bear this in mind when we examine the state of ideology and the much commented upon moral decline in contemporary China. I shall argue that the power of ideology is to a great extent, although not exclusively, built on moral beliefs, social norms and values, and that its effectiveness is linked to the ethos of the society in which it operates. Consequently, when the social fabric starts to erode, so too does the power of ideology. I shall argue that the party's links to social norms and values have fractured in two crucial places. First, in terms of its being anchored to general social norms and values, unconnected with any social movement as such. Second, it is broken in terms of what Weber called charisma. The party, or its representation through the Ultimate Leader, has been emptied of heroic charisma. What Mao Zedong had in abundance, and Deng Xiaoping had to a lesser extent, does not apply to a Jiang Zemin. Jiang's popular nickname, Qiang Toucao, is a reference to the grass blowing in the wind, connoting opportunism and unprincipled pragmatism or bureaucratism. Jiang does not possess the charisma won through armed struggle in war and revolution, nor is his name linked to the grand narratives of heroism in any way. Both these 'broken links' point in the direction of a waning normative power. Ideology has lost its social and charismatic moorings.

I have elsewhere written on the uses of the norm as the basic element of a control system, pointing out the recurring patterns of Chinese 'exemplary norms' of Confucian as well as communist heroism and selfsacrifice. ${ }^{3}$ These have always been ideal norms orchestrated from above and used for ideological purposes. However, despite the many examples of resistance against such 'exemplary norms,' the ethos of collec- 
tivism and the hopes of communism did find support and resonance among the general public to a much greater degree during earlier periods in the history of the People's Republic of China. It is hardly a controversial standpoint to claim that we have seen an erosion of this ethos during the reforms.

In the latest important ideological campaign (the 'three representations' [san ge daibiao]) leading up to the 16th Party Congress, Jiang Zemin addressed the role of the Chinese Communist Party, stating that: 'It is essential to have the strong leadership of the Communist Party of China. Otherwise, the country will fall into disunity and break up.' ${ }^{\prime 4}$ I have gone back to Franz Schurmann's now classical Ideology and Organization in Communist China to see whether his description can give us clues about the present state of the party, and its future direction. Schurmann questions whether the complex structures of organization in a socialist society could continue to function without the Communist Party:

[I]s the Communist party the keystone to the whole structure, so that its disappearance would mean the collapse of the structure? The weight of evidence, in my opinion, is that it is so; given Communist-type organization of state power, a Communist party would have to be created if it did not exist. ${ }^{5}$

It is the scenario of breakdown which haunts as well as legitimizes the leadership of the CCP. The party has utilized this breakdown scenario in their propaganda, trying to convince people that the $\mathrm{CCP}$ is China. From this perspective, if the party collapses, the whole nation will surely disintegrate and break up. This warning, together with the frequent references to the disintegration of the Soviet Union, has clearly been one of the party's strongest arguments of legitimacy over the last decade and more. The regime is constantly reminded of the possible breakdown in everything from the nation's own dynastic history to the more recent events of Cultural Revolution, via the breakdown of the Soviet Union, to their own experiences of mounting social unrest and disorder.

Li Tieying, Politburo member and leader of the Chinese Academy of Social Sciences (CASS), addresses the question by describing the disintegration and final breakdown of the Soviet Union as the 'most painful lesson of socialism' ever, and urges the party to avoid such an experience in China. Li sees a need to prepare and renew the party for the road ahead and the dangers to come, and advocates purely pragmatic 'constant change and renewal' as the way out for the party. ${ }^{6}$ Li Tieying's position recognizes that the charisma of the Great Leader is gone, and that ideology is the medium through which a routinized party can regain unity and achieve renewal. 
This utilitarian scenario claims that 'constant change and renewal' and pragmatic readjustments to the realities of a rapidly changing China will save the party and keep it in power. In this sense, reaching out to new groups becomes a rational way forward for the party. Ideology may have been downplayed since the time of the great campaigns, but it has not lost its validity as a unifying and renewing force. Ideology is played out, however, against the backdrop of an alternative breakdown scenario. In such a development, the very processes and techniques implemented to uphold power will instead contribute to its demise, paradoxically leaving the party 'like the sorcerer, who is no longer able to control the powers of the nether world whom it has called up by its spells. ${ }^{7}$

Schurmann defined ideology not as a thinking characteristic of a class or individual, but as a manner of thinking characteristic of an organization. ${ }^{8}$ As we shall see, the definition fits well with the present situation, and we therefore need to look at the party's organizational rationality and techniques of management. The transforming effect of ideology is an important issue. Any party or organization must eventually face the moment of routinization, Schurmann argued, pointing out that communist parties had always resisted routinization; 'sometimes by purges, more often by renewed outbursts of ideological activity.' This is the case, he claimed, both with younger revolutionary parties as well as the more bureaucratized ones: '[I]deology remains a latent instrument which can be reactivated if the leaders and the external situation call for it. ${ }^{19}$ In other words, ideology does have the rational function of renewal, and in addition, a potential unifying function countering the dangers of growing routinization and stagnation. Ideological change stands out as the preferred solution if we think of the alternative massive purges that plagued the party for so many years. They may have renewed the party, but in the end wore out both the organization and the people. The purges made people cynical and destabilized China as a result.

Cynicism is, however, an aspect of ideology too, and this fact should not be overlooked. Schurmann maintained that legitimacy flows from the leadership's ability to link decisions to the broad and accepted values and norms in society at large. In organizations based on powerful values and norms, consciousness is important. Values can only be held consciously, and norms can only be acted on, if people understand them, Schurmann contends. ${ }^{10}$ Consequently he warns that: 'Cynical playing with ideology has often had disastrous results for those who saw it simply as a useful tool. ${ }^{11}$ We shall argue that such cynicism originates in the lack of social moorings of the new ideology and in the manipula- 
tion of social norms and values that follows. While reaching out to new elites, the party keeps its original legitimizing norm of being the 'vanguard of the working class.' One important aspect of the current ideological campaigns, however, is that they are linked to norms of an order other than the social - these can be termed exemplary norms. Such exemplary norms may prove to be a rather unstable substitute for the real thing. We shall later look more closely at how ideology is reactivated and how it could possibly backfire - through the campaign of the 'three representations.'

\section{Party Ideology, Exemplarity and the Social Norm}

One need not look for an internally consistent ideology in post-Mao China, because the socialist rhetoric is no longer promulgated as a credible ideology. The principal tenet is rather to uphold the party's prestige structure. While the party is reaching out to include new economic elites, it still utilizes its former social values of serving the people. According to the latest definitions of ideological correctness, the party represents 'the people's democratic dictatorship' (renmin minzhu zhuanzheng) led by the working class and based on the worker-peasant alliance. ${ }^{12}$

The party is fast developing into a self-proclaimed national and socialist party, with an emphasis on the 'national,' but a strengthening in the rhetoric of the 'socialist' element. Ideology has increasingly become a heterogeneous mixture of nationalist, socialist and capitalist strands, played to the tune of outworn socialist soundbites. The focus is not on internalizing specific social norms and values, more about defining a set of 'standards' of correct behaviour, or rather correct ways of defining the world. One observer has seen in this development a transformation of the party 'from a principle-oriented party to a utilitarian party' and goes on to define it as a corporate party. ${ }^{13}$ While this may be an oversimplification (the party was always pragmatic and utilitarian), it does say something about the relative strength of its approaches. Perhaps one could argue that the cloak of ideology is threadbare and that the utilitarian undergarments are becoming more and more visible. At least the idea of a corporate party or a managerial party serves as a good description of the present situation.

The party has realized it must change, but is unwilling to let go of some of its socialist verbal baggage. There is a striking contrast between the realities of reform and the continuing invocation of communist ideals. Maintaining control and upholding power have always been important aspects of the ideology, but ideological campaigns now seem to 
be played out without striking any deeper resonance with the basic norms and values of society. Maoism became increasingly ritualized after the Cultural Revolution, and people, as well as the state and party bureaucracy, increasingly came to doubt official ideology. The political demobilization experienced after the Cultural Revolution may have effectively curtailed the penetration of ideology into the everyday lives of the people, but it could not stop the general disillusionment about the party ideology as such. People are now merely going through the movements, and for the party it has been particularly important to control those movements.

The party battle-cry to 'become rich first' was crucial in kick-starting the economic reforms, but at the same time increased the opportunity for corrupt operations. Cynicism about ideology and increased opportunities for private enrichment gradually enhanced private rationalities both within and outside the party. The game of ideology led to a 'moral order' full of disillusion and simulation. Possessing the correct definitions of the present order seems to be the stuff of which power and careers are made. Few Chinese sincerely believe they are developing a socialist society fundamentally different from and superior to capitalism. For the party and its ideology, it is just a matter of defining any development as a renewed and advanced form of socialism. At the same time the party still bases its legitimacy and power on its traditionalist communist identity. Consequently, to 'let someone get rich first' must be defined as a valuable contribution to socialist collectivism and solidarity, while the market has to be redefined as a socialist invention of 'market socialism,' and the good capitalist must become a 'model worker.' According to official Chinese propaganda, it is 'spiritual civilization' that makes the system different from and superior to the capitalist West. This is in reality not so much about moral superiority as it is about the ways to uphold social order. Legitimacy flows from the dual ability of the regime to uphold order and sustain growth.

The present ideology is full of nationalist hints about the advanced state of Chinese history and culture. Socialist rhetoric and exemplary models are formed into new legitimizing narratives of growth and order to defend the fading grand narratives of a once-orderly socialist past. In both the memories of past greatness and the dreams of greatness to come there are integrative elements - and in both there are dangers. According to official Chinese thinking, the best way to cope with such danger lies in the 'exemplary norm.' 
It is one of the fundamental assumptions in the Chinese theory of learning that people are innately capable of learning from models. In addition, rule by morality was more widespread in traditional China than rule by law. Chinese society is undoubtedly a disciplinary society in many senses, but it is also an educative society. A combination of the disciplinary and the educational constitutes what could be termed an 'exemplary society. ${ }^{14}$ A discipline based on social norms and values is more durable than one based on outer force only, because it seeks to bind people to society with their own ideas. This is also reflected in the power of the party. It remains strong only as long as its élan vital derives from the values of the grassroots of society. It is linked to power in a way less likely to manifest force or violence. Regulation through the norm is based more on willed consent, and functions as a positive restraint. One should not forget that the Communist Party was once based on strong mass movements and popular support, and that its initial success originated from such social moorings. When ideology and the social norms are closely linked, one may refer to ideology as something one $i s$, in the sense of being part of one's identity. This is a rare phenomenon, perhaps one resembling religion. More generally, ideology would normally be defined as something one has or as something one uses.

When the norm is not allowed to fluctuate naturally like a social norm, or when a norm prescribed from above no longer has a basis in social practice, then it turns into an exemplary or 'super-social norm.' This norm is prescribed from above and, in the case of today's China, it merely represents the party's power to define reality. The party no longer represents the social norm, it defines and stands above the norms of society. The enforced exemplary norm might be crucial in upholding order and maintaining the rule of the party for a shorter or longer period. At the same time, the inflexibility and the lack of social moorings represented by the 'super-social' norm can lead to a general erosion of order. In terms of the party's power, we might talk of an eggshell theory. On the outside the egg looks nice and fresh, but inside it could be rotten. The shell becomes more and more brittle, but this may be hard to detect on the surface. Change may come suddenly and dramatically. Indeed, as soon as the eggshell cracks, the party Humpty-Dumpty will be impossible to put together again because there is no longer a cohesive social normative basis, nor an economic incentive for upholding its leadership.

Of course, the party's power is not solely predicated on the normative social fundamentals of that organization. The party apparatus has a string of organizational and structural power bases that allow it to 
stay in power and uphold order by coercive means for a long period without recourse to any normative mass base. The point here, however, is to focus on the importance of such a base, and show how the lack of social moorings could weaken and challenge the entire organizational structure. Like Schurmann, I want to stress this fundamental social aspect of party power without harbouring any illusions that there exists a one-toone relationship between this base and the actual power of the party.

\section{Countering the Bureaucratization of Charisma}

The exemplary norm is about guaranteeing order and stability in a society through the prediction of people's behaviour. The quest for order and predictability is the very core of the 'spiritual civilization' presented in party propaganda. The ideological campaign is about how to bind people to new definitions of exemplary norms. These definitions represent a means to counter the effects of bureaucratization as well as oiling the rusty machinery of the party, updating it and making it more effective in carrying out sweeping economic reforms.

At this juncture we need to make a detour to educational theory to look at some of the basics tenets of party ideology and how it is supposed to function. Our focus will be on how model images are administered, which is a central theme in the three spheres of education, ideology and propaganda. Models can be seen as a way of ordering a society. They may be part of a culture and be based on commonly held social norms; however, models can also be imposed from above. While cultural heroes may endure for centuries, others come and go virtually unnoticed. The ideal of Chinese modelling theory, however, is still that models should emerge from below and not from above. ${ }^{15}$ Models emanating from below have social and cultural moorings that render them extremely stable and effective in holding society together. The imposed model, by contrast, lacks such moorings: it is a figure constructed 'outside' society itself. In China, we can find examples of both these types of models and modelling, but the new models increasingly resemble constructed images, considerably reducing their importance. According to worried Chinese educators, 'a devaluation (bianzhi) of models has taken place' as models become further and further removed from people's own daily experiences. ${ }^{16}$

The most important function of ideology and its exemplary models has been to represent an alternative to bureaucratic authority. Modelling in itself is a technique for achieving authority based upon the charismatic character of the model or the hero. Models represent charis- 
matic authority in Chinese society, and can take the place of charismatic leaders in their absence. What is happening in China today is an example of what Weber characterized as the 'routinization of charisma.' In his description Max Weber applies the term charisma to a personality 'regarded as of divine origin' or as 'exemplary' (vorbildlich) or as one possessing mythical and therapeutic wisdom. ${ }^{17}$

Cultural heroes, leaders and organizations all initially possess elements of charisma, but as time drags on and bureaucracies expand, this process is subject to the erosive effects of daily life and reality. Weber described the general routinization process that befalls charismatic authority thus:

In its pure form charismatic authority has a character specifically foreign to everyday routine structures. The social relationships directly involved are strictly personal, based on the validity and practice of charismatic personal qualities ... Indeed, in its pure form charismatic authority may be said to exist only in the process of originating. It cannot remain stable, but becomes either traditionalized, rationalized, or a combination of both. ${ }^{18}$

The last sentence here is particularly important. Neither the charisma of the 'great leader' nor the exemplary model has proven stable in today's China. As in Weber's description of charisma, Chinese propaganda circles are now grappling with the problem that charismatic authority only seems to exist in the process of originating. Traditionalized charisma comes back as nostalgia of past greatness, and nationalism can sometimes be seen as an attempt to regain that type of charismatic power with all its rhetoric about the great Chinese past, the more than 5,000 years of Chinese civilization, etc. ${ }^{19}$ As for the present, there is the problem of routinization and rationalization, and the attempts at renewal and unity through ideology do not possess the stability inherent in original charisma.

There is another trait of the Chinese past, not mentioned in the exemplary accounts of ideology and great harmony - namely, that of rebellion. Chinese historian Jin Guantao observed that Chinese feudal society was repeatedly shaken by social upheavals. ${ }^{20}$ Violent and apparently successful rebellions repeatedly made old dynasties collapse and new ones appear. The typical historical scenario described by Jin is that, after an initial period of rest and popular support, the bureaucratic apparatus is gradually blown up. Corruption, disintegration and finally great chaos set in, leading to rebellion and a collapse of the dynasty. A new emperor then ascends the throne, and the crisis is met by a reform. The bureaucracy is simplified, and a restoration of the authority of the dynasty takes place as the new emperor apparently reinstates the basic social values of the past. The peasant uprisings had a cleansing effect as they got rid 
of bureaucracy and its power plays, but then started to restore the same structure, trying to build the new with the old.

We cannot here discuss Jin's work in detail, but one point he implicitly underlines is the effects of the routinization or rationalization of charisma. His work was thoroughly condemned in China in the late 1980s, and it was read into the present as a comment on the moribund state of the party during the 'Deng dynasty.' As a Chinese intellectual, Jin found no hope in mass rebellion, which he saw in the picture of endless repetitive cycles of feudal reproductive ultrastability, but his work nevertheless centred on the feared scenario of breakdown, a still lingering source of anxiety during the present 'Jiang dynasty.'

\section{The 'Three Representations' and the Importance of the Party}

Jiang Zemin's campaign on the 'three representations' (sange daibiao), was first presented in February 2000, and was consolidated in his 1 July speech at the CCP's 80th anniversary in 2001. This central campaign has been presented as 'a new development of the Marxist theory of party building' and as a campaign for 'strengthening the party in the new period. ${ }^{21}$ Jiang's speech was acclaimed for 'creatively enriching and developing Marxism,' and the same party commentary has focused on its intent to counter 'Western hostile forces' in their attempt to 'Westernize and break up our country.'22 The central tenet is about the Communist Party modernizing the nation by representing the 'development of advanced productive forces,' 'China's advanced culture,' and the 'fundamental interest of the overwhelming majority of the people.' The 'three representations' can be seen as an extension of the theory of 'two civilizations' applied to the party. The 'two civilizations' campaign is addressed in Jiang's speech. The outline of that campaign was originally formulated as early as in 1982, and presented by Hu Yaobang at the 12th Party Congress. In that campaign, material civilization (wuzhi wenming) stood for the productive forces or economic growth, while spiritual civilization (jingshen wenming) referred to China's advanced culture, in effect social order and stability. ${ }^{23}$ The task of serving the people follows from the successful implementation of the two civilizations. ${ }^{24}$ The theme of culture, morality and the 'spiritual' remains a central motif within the party. Ideology is still viewed as the cohesive element of the party, although we sometimes find economistic interpretations of spiritual culture along the lines of the Dengist emphasis on the productive forces. 
Li Tieying gives such an interpretation of the present campaigns when he defines 'advanced culture' first and foremost as 'enterprise culture,' in particular the 'advanced cultural achievements of foreign enterprises,' emphasizing how much the party can learn from such an approach. ${ }^{25}$ Li's point is interesting, and we are well advised to follow his line of thinking and regard the party ideology as some sort of enterprise culture linked to the efficiency of the corporate party. We have already quoted Li's emphasis on 'constant change and renewal'; indeed, 'adapting to the situation' has become the watchword in the 'three representations' campaign. The major reason why the party has been able to maintain its power up to this point is that it 'retains its advanced nature,' according to one Xinhua report. The description of its advanced nature is very pragmatic and businesslike: '[T] he party is able to judge the times and seize upon situations, advance with the times ... [and] make efforts to suit the needs of the times.' ${ }^{26}$ The campaign is about streamlining the party to face the challenges of a modernizing China.

The 'mass line' gets a pragmatic interpretation of order in the 'three representations' campaign. If corruption is not effectively punished, so goes the argument, the party will lose the confidence and support of the masses. This might upset order, and in its turn destroy the party and the country. ${ }^{27}$ The party's theoretical journal Qiushi focuses on the chaotic public order, in particular in the rural areas, reminding us again of the importance of social order and fear of rebellion..$^{28}$ The 'three representations' have further links to the anti-crime campaigns, and are said to be effective in cracking down on criminal syndicates and 'evil forces' as well as guaranteeing rural stability. ${ }^{29}$

A crucial theme of the campaign is the criterion for party admission. The CCP used to be seen as the organized expression of the will of the proletariat. In Jiang Zemin's 1 July speech there is due reference to the old slogans of the party being the 'vanguard of the working class' (jieji xianfengdui). At the same time there are many references to the 'new social strata' (xin de shehui jieceng), who have 'contributed to the development of the productive forces'; most notably consisting of 'entrepreneurs and technical personnel employed by scientific and technical enterprises in the non-public sector (minying keji qiye de chuangye renyuan he jishu renyuan), managerial and technical staff employed by foreignfunded enterprises, the self-employed (getihu), private entrepreneurs (siying qiyezhu), and freelance professionals. ${ }^{30}$ With a twist of its original meaning, we might say with Lasch that the party has indeed seen a 'revolt of the elites. ${ }^{31}$ While the ideological façade still describes the 
working class as the 'masters' of Chinese society, a more realistic picture was presented in a book issued by the Academy of Social Sciences in January 2002. ${ }^{32}$ The book operated with five categories, from the upper social strata (shehui shangzeng) to the lower stata (dizeng), placing the working class in the two lowest categories, the middle-lower (zhongxiazeng) and lower (dizeng) strata. The book was first sold on the open market, but was soon withdrawn and circulated for 'internal distribution' only. Rumours in Beijing tell us it had a potentially destabilizing content.

Perhaps even more important than the formalized entry of entrepreneurs into the party (they have to some extent already been admitted since the 13th Party Congress), could be the announced revision of the Marxist theory of labour and labour value. In the old party statutes it was explicitly stressed that members should 'not exploit the labour of others.' The conditions facing the Chinese leaders of today is, according to Jiang:

Quite different from those the founders of Marxism were faced with and studied. In light of the new conditions, we should make a thorough study of the theory on labour and labour value in a socialist society with a view to achieving a better understanding of this theory. ${ }^{33}$

The party's wielded power over theory, together with the lack of censorship by an absent international Marxist movement, allows it to impose any exemplary organizational norm on its members without resistance. The party can no longer be accused of being dogmatic or even Marxist, but should rather be seen as a managerial or utilitarian party where 'practical ideology' may even lead to the revision of its 'pure' Marxist basis. Many would welcome such a utilitarian approach to pure ideology, and the Chinese leadership sees in this renewal the basis for upholding and enhancing its power. These congratulatory statements should, however, be subject to further analysis.

The labour theory of value lies at the very core of Marxism and its theory of surplus value and exploitation. Jiang's 'better understanding' of the theory is clearly in line with admitting capitalists into the party, and is aimed at accommodating the paradox of exploitation within an allegedly socialist China. On the one hand, this can be conceived as a realistic approach to the changing realities and class relations in today's China. On the other hand, it will be a massive task to legitimize the party as a communist party if the basic theories of exploitation are eliminated.

The economic reforms have created a new type of factory worker as millions of migrants pour in from the rural areas and as workers in the state-owned enterprises lose their jobs. In the rural areas between 150- 
200 million peasants have failed to be absorbed into agriculture and rural industries, thus creating a vast tide of labourers streaming into the cities. Unlike the zhigong zhi, who enjoyed lifetime employment provided through the work unit, the new workforce is often made up of people who have travelled long distances to work on a temporary basis 'for a boss.' The new type of workers are referred to as dagong zhi, or for lack of a better word in English, as 'migrant workers.' There has been severe discrimination against such migrant workers. They suffer the abusive consequences of the invisible hand of the free market as well as the all too visible hand of disciplinary control, and experience something akin to urban apartheid. Accounts of the living conditions of these workers reveal shocking details of abuse and exploitation reminiscent of the primary stage of capitalism described by Marx in the footnotes to Das Kapital, or in Charles Dickens' novels and stories dating back to the Industrial Revolution. ${ }^{34}$

The unemployment rate in urban China in the late 1990s was 7.5 percent. ${ }^{35}$ Some senior Chinese economists have estimated joblessness rates as high as 20 percent in urban China in the near future, and massive regional imbalances exist. ${ }^{36}$ At the same time, the differences between classes as well as between urban and rural areas have increased dramatically. Depending on the source of income data, the Gini coefficient in China has just reached 0.50 , moving the country rapidly towards the category of countries with the level of most unequal income distribution. ${ }^{37}$ Social inequality has become a public concern, and a recent survey showed that more than 80 percent were 'dissatisfied with the general mood of society,' and the 'widening gap between the rich and the poor.' The same high percentage, in particular workers and women, had felt 'increasing pressures in their lives' over the last year. ${ }^{38}$

The legitimate rule of the party seems to reside in its ability to deliver in terms of economic growth and social order. Signs of an incipient economic crisis are however alarming. Premier Zhu Rongji recently claimed that the Chinese economy would have collapsed in 1998 without the state-initiated spending that is currently taking Beijing's government debt to record levels. Not all economic analysts concur with the mainstream view that the Chinese economy is a success story. Like Professor Krugman, who saw the warning signals before the Asian crisis, Professor Thomas Rawski has argued that China's economy may actually have been contracting since 1998. ${ }^{39}$ The high official growth rates seem strangely out of touch with certain evident trends in Chinese society. The migrant population camp out under bridges and at railway sta- 
tions, many of them already suffering the effects of long-term unemployment. Block after block of abandoned construction projects in cities strongly suggest that the money is drying up. Moreover, how can it be the case, Rawski argues, that energy use is falling in a booming economy? This phenomenon is unprecedented in economic history. Numerous reports of protests and violent clashes between police and civilians also attest to an emerging breakdown in social stability. ${ }^{40}$

Stability and exploitation are interlinked phenomena. It will take a massive amount of 'spin doctoring' to eradicate the issue of exploitation in line with Marxist theory. Here we encounter the core of the problem. The power to define what Marxism is about is much more important in terms of ideological 'ordering' and party power, than are the real issues of factual exploitation. The real problem of exploitation will certainly not disappear through an ideological revision of Marxism, and after all, the Communist Party is still legitimized by the 'support of the labouring masses.' One obvious alternative for the party would be to rid itself of Marxism altogether and create a minzu dang, a 'people's party. ${ }^{41}$ The gains would not be substantial, however, since the party will never cease to be a 'Marxist party' as long as Marxism continues to be defined according to the realities formulated by the party itself. In this sense it does not really matter that politics is losing its links with orthodox Marxist ideology. The 'three representations' is not about the problems of exploitation and about 'serving the people' at all, it is simply about keeping the 'corporate party' with its prestige structures in power. Some who believe the party is moving towards greater openness and pluralism may be disappointed. According to one analysis of the 'three representations,' in solving the more complicated inherent contradictions among the people, 'the ideology absolutely should not become pluralistic. ${ }^{12}$

One might argue that the party now represents the interests of capital, insofar as party membership is used as an important instrument to develop capital. Such membership is now sold as a commodity, and paid by exemplary obedience to the party statutes. The party has swelled its ranks at an impressive pace over the last decade: from 50 million members in 1990 to 66 million in 2002. This figure constitutes nearly 5 percent of the entire Chinese population. ${ }^{43}$ 


\section{The Communist Ethic and the Spirit of Capitalism}

Jiang Zemin is not interested in the concept of class as such. He is letting the capitalists into the CCP while upholding the party slogan of being the vanguard of the working class. However, the main admission criteria are becoming more and more technical and pragmatic:

The main criteria to admit a person into the party are whether he or she works hard wholeheartedly for the implementation of the party's line and programme and meets the requirements for the party leadership. ${ }^{4}{ }^{4}$

This person should be judged 'mainly by his or her political awareness, moral integrity and performance. ${ }^{45}$ These are routinized technical and organizational criteria that reward exemplary loyalty rather than emphasizing the class line. We have, of course, always seen such criteria for admission to the party, but now they seem to be standing alone without any reference to class or class consciousness. An article in Qiushi stresses technical as well as managerial skills, and emphasizes the behaviour-oriented criteria for party admission:

The two basic requirements of "conscientiously struggling for the party's line and guidelines" and of "meeting the criteria for party membership" should be handled as one single criterion: observation of actual performance (xianshi biaoxian). ${ }^{46}$

In addition, entrepreneurs should pay their taxes according to regulations and reinvest in production to be admitted. The will to reinvest for the good of the nation seems to represent for the entrepreneur class some sort of Weberian predestination - not in heaven, but as success inside the party. According to the new admission criteria, a Benjamin Franklin would surely have been admitted although his Protestant ethic would have been redefined as a communist one. The stress on exemplary conduct is also made clear by Jiang's remark that governing the country by the rule of law (fazhi) should be combined with the rule of virtue (dezhi). ${ }^{47}$ 'Evil' seems to be a very useful political concept in contemporary politics, not only in the simplified worldview of the Bush administration. People with 'evil minds and unhealthy conduct' should be kept out of the party, according to a political commentary in the People's Daily. The article goes on to claim that the party 'must ensure that good defeats evil, good never brokers a compromise with evil, and that good cannot be defeated by evil.' 48

Since exploitation is soon to be abolished with one stroke of the brush, then the good cadre and the good party member are the only 'guarantees' left to secure the well-being of workers and peasants. The many references to high ethical standards, moral integrity, and high political- 
ideological consciousness (sixiang zhengzhi juewu) are replacing the social basis of the party. ${ }^{49}$ Class consciousness has become a no-word, and exemplarity has become the important factor of management control.

The stress on morality has of course a long tradition in China, and Confucian as well as communist morality have continuously been important elements of social control. The phenomenon now reappears in new forms. Jiang's new ideology means the final abolition of the class line while upholding its rhetoric. The heavy doses of morality that characterize the recent campaigns are supposed to bridge or harmonize the increasing distance between reality and ideology. It remains to be seen whether this gap can still be bridged.

\section{Rituals of Ideology and the Mantra of 'Serving the People'}

It would be tempting to see the ideological campaigns of the party through the satirical eyes of an Aleksander Zinoviev, as the techniques of a machine recycling its own absurdities, and just look at the emptiness of their rhetoric. However, to confine the analysis to that level is to underestimate the serious game of ideology. ${ }^{50}$ One fruitful approach to analyse the mechanisms and contents of ideological campaigns is to use the language of games, theatre and simulation. It is necessary to look at the empty forms of the campaign, and to distinguish its vacuous and bombastic presentation from what remains valid and important in its content. Ideology has become a vital power game of using the right words to describe things of importance. Perhaps there is a parallel here to the Confucian term zhengming. The zheng, however, in this case no longer refers to the correlation between the name and the object, but that between the name and what is in the more powerful listener's head. ${ }^{51}$

To uphold the façade of the party, there is a pressure to make public statements that express what should be rather than what is. ${ }^{52}$ An inflated use of superlatives and ritualistic optimism about the present and the future situation of the party and the country have come to characterize the language of an ideological campaign. The campaign language has its own rules and internal logic, and at times may sound repetitive and even comical to an outsider. It is a language of power, and the script needs to be read between the lines. First of all there are always realities to be identified and described. After all, without stating the problem to be rectified, there is no need for an ideological campaign. The existing problem is presented in a somewhat modified form, indicating the real problems without taking the description to excess. The gravity of the 
problem is always formulated in the hypothetical question of what would occur if the problems were not to be addressed in the right manner.

Through the party's presentation of the 'three representations,' we get a faint glimpse of the lack of enthusiasm and the absence of charisma in a bureaucratized organization. To justify rectification, the party admits that ideological and political work is hard to do in the new situation, and that the campaign has run into problems leading it to become a mere formality. ${ }^{53}$ They also admit that 'some comrades have weakened their communist ideals,' and that they have started doubting whether Marxism and socialism work at all. It touches on the bureaucratic arrogance of leading party cadres, pointing to the phenomenon that 'the worse their temper, the higher their posts. ${ }^{54}$ It is also admitted that the party's ideological work is facing challenges from Western values and the diversification of economic factors and interests as well as from the internet. ${ }^{55}$ Lastly, it admits that: 'The task of educating and administering party members and cadres is harder than at any time in the past,' owing to the fact that 'many party members and cadres are substantially inferior to the older generation. ${ }^{156}$ The situation has been deteriorating for many years already, and even people in charge of ideological education have developed cynical attitudes towards such education. According to one survey, only 8 percent of them bother at all about ideological education. ${ }^{57}$

Let us here return to the empty rhetoric, and what could be called the 'game of the always excellent situation.' Despite the described gravity of the situation, the severe difficulties are as a rule summed up by pointing to 'the extremely favourable conditions for properly carrying out ideological and political work. ${ }^{58}$ This game is followed up by another ritualistic way of staging the campaign: the game of successful implementation. Ideological campaigns are nearly always summed up in ritualized notions of success and enthusiasm. In a typical example, the participants of one recent campaign on party member conduct, the 'three stresses' (san jiang), (stressing politics, studies and healthy trends) had 'improved their spiritual status, become more enthusiastic, made new progress in their work,' etc. ${ }^{59}$ The florid descriptions of success and 'ground-breaking improvements' are well known, and few believe that such reports mean anything other than that the educated participants can now breathe more freely again. The message has been disseminated, and the things of importance have been made clear for everyone to obey and to use. 
There is a lot of ritualized talk in Jiang Zemin's speech on the 'three representations' about the importance of 'sharing the common faith with the masses' and 'taking the fundamental interests of the people as the starting point and purpose. ${ }^{160}$ Ideology is said to represent an important contribution in facilitating China's development and stability, and the methods reveal a fundamental belief in the power of example. The People's Daily urges leaders to set the example in showing good conduct, and urges the party to 'improve the party's construction of conduct. ${ }^{161}$ Emulating and admiring advanced models, and striving to become advanced models persist as fundamental tenets of ideological campaigns. During the sange daibiao, special efforts were to be made to carry out such political work among laid-off workers to help them solve difficulties. ${ }^{62}$ In line with the new practice of assimilating capitalists and entrepreneurs into the party, they are even included in the working class. It was recently suggested that representatives from these groups be awarded the title of model workers. Han Xiya from the official AllChina Federation of Trade Unions argues that this is a bad idea, and suggests that praise should perhaps be given in a different form, and the entrepreneurs be awarded another title of honour. ${ }^{63}$ It should not be difficult to imagine that the enthusiasm involved in emulating your boss as a model worker for sacking you in order to strengthen the nation might prove of limited value for a recently laid-off worker. A commentator in Hong Kong sums up the situation for workers and peasants in China by stating that 'in Jiang Zemin's "new age", workers have been reduced to real "proletarians" and peasants to "hoodlum proletarians"... Workers and peasants have been reduced to a weak group in Chinese society, to whom the least attention has been given. ${ }^{164}$

Continued failure on the part of the Chinese administration to confront the problems of laid-off workers and reduced peasants' livelihood have led many from these labouring classes into desperate circumstances not easily to be remedied through ideological campaigns.

\section{Rationalization or Traditionalization}

In less routinized organizations, the charisma of the 'great leader' can have immense importance, as history has shown us with devastating clarity. At this 'moment of origin,' however, it is still the values and norms of revolutionary movements or organizations which are powerful enough to make people act in strict compliance. Will the fading of revolutionary fervour and mounting routinization and bureaucratization lead to a stronger, legally based and less person-centred ration- 
ality? Will the utilitarian state simply be drawn towards rational solutions and legal reason? Not necessarily. Schurmann argued that in a bureaucratized and highly routinized organization, it is not so much charismatic personalities or revolutionary values but human relationships of a non-charismatic kind that provide the dynamics which the organization needs to function.

[S]uch organizations often continue to function precisely because of the particular individuals in it who play the leading roles - if they are transferred, it usually has significant consequences for the functioning of the organization; men are more important than the roles they are required to perform. ${ }^{65}$

Personal relations between party leaders, their guanxi, subsequently do not become less important, but rather more important for the daily functioning of the organization. Schurmann goes on to explain that: 'routinization of such an organization would simply make the party into an elite club in which the political leaders meet to renew their solidarity.' ${ }^{66}$ We see a traditionalization of charisma here. Weber seems right in his claim that charisma cannot remain stable, but becomes either traditionalized, rationalized, or a combination of both.

We see the attempts of the campaign to revitalize past charisma by elevating Jiang Zemin to a higher level in order to enter the hall of fame together with Mao and Deng, but there is also talk of a united leadership. The repeated references to safeguarding the core of the party has much to do with the particular individuals' relevance for the perceived stability of the nation and the party ${ }^{67}$ Jiang Zemin is now constantly referred to as being at the core (wei hexin) of the party, as were Deng and Mao before him. Still, however, only Marxism-Leninism represent an 'ism' (zhuyi), Mao holds the position of Mao Zedong 'Thought' (sixiang), and Deng's ideas are referred to as Deng Xiaoping 'Theory' (lilun). Jiang might be at the core, but he is merely 'holding the banner of Deng Xiaoping Theory.' ${ }^{68}$

In drafting The Selected Works of Comrade Jiang Zemin, the drafting group has drawn up a document listing Jiang's 'ten major achievements,' and the 'three representations' campaign is being elevated into a 'development of Marxism and Deng Xiaoping Theory.' In the army, we have recently seen a faint resemblance to Mao's Little Red Book, namely the 'selected important exposition of Mao Zedong, Deng Xiaoping and Jiang Zemin on strengthening ideals and convictions. ${ }^{169}$ There is apparently opposition to Jiang Zemin's newest campaign, and the attempts to strengthen Jiang's position. ${ }^{70}$ In particular, the opposition against these developments comes from the old guard of elder statesmen (perhaps 
belonging to an earlier status quo that Jiang already has left behind) like Wan Li, Bo Yibo, Yang Baibing, Wang Enmao and Wang Hanbin who are claimed to be 'extremely disgusted with the lavish praises of Jiang Zemin.' The criticism here seems to be concentrated against the person of Jiang Zemin more than against any particular ideological or political issue. The opposition has used extremely harsh words to describe the campaign, but the critique is phrased in very general and sweeping statements. It is claimed that it has been implemented without the test of practice, that it is confusing and not easy to grasp, and worst of all, that the whole campaign is aimed at developing a feudal personality cult around Jiang Zemin.

More principled and less person-oriented criticism has been heard. Recent warnings against de-Maofication should be seen as a reaction against Jiang's ideological campaign straying too far away from the old ideology. ${ }^{71}$ Jiang Zemin took action and suspended the leftist journals Zhenli de zhuiqiu [Seeking Truth] and Zhongliu [Midstream] which propagated such ideas and generally opposed Jiang's definition of the truth. Yu Quanyu, the editor-in-chief of Zhenli de zhuiqiu said in the final issue before suspension that a 'faction of capitalist roaders' inside the party would lead to its disintegration. ${ }^{72}$

\section{Private Rationalities and Cynical Games of 'Actual Performance'}

Let us go back to the techniques of ideology in the former Soviet Union, and look at the Chinese ideological inventions of the capitalist model worker and the dawning eradication of exploitation in the light of those techniques. Mikhail Epstein, based on experiences from the former Soviet Union, has defined the concept of ideology in terms of the tactics involved in obtaining or enhancing political power, claiming that the only value left in the language games of ideology is that of power. The recent game of Chinese party ideology seems close to what Epstein identifies as 'ideologemes.' The term describes the use of ideological expressions containing contradictory elements from both left and right, black and white, expressing the definitions of the present situational truth, a form of Orwellian 'new speak.' Could this be termed Marxism? In Epstein's view, Soviet ideology developed beyond any particular rational or irrational system, and became reality itself. ${ }^{73}$ Soviet Marxism lost its specificity as a particular ideology and became instead 'an allencompassing system of ideological signs that could acquire any significance desired. ${ }^{74}$ 
It has been observed that in China too, ideology has survived only by absorbing a mixture of communist and capitalist ideals. In addition such ideologemes have expanded to shape and pollute debates both inside and outside the party. ${ }^{75}$ The ideology of ideologemes no longer depends on particular views and ideas as such, but turns into a power game of how to say things in a correct way at the correct time. The power to be able to define becomes the ultimate power, and at the level of ideology evaluations based on personal judgements desires or preferences seldom enter into the process of communication. A cadre can truly say with Wittgenstein, 'The limits of my language mean the limits of my world.' Mastering the language of ideology - the language of the party - becomes the way through which power is gained and careers are shaped. In other words, ideology becomes a form of social or ideological capital or a moral economy where 'correctness' or 'exemplarity' can be shored up and used for all kinds of political transactions. This is not a language to be believed or a truth to be internalized, nor a value or a social ideal to be cherished, it is merely an exemplary language to be obeyed and to be used. It is a pure instrument of power.

Let us go back to the party admission criteria, and the remarks on actual performance mentioned earlier in connection with the management character of such criteria. The actual performance (xianshi biaoxian), says Jiang Zemin, is what defines the quality of the cadre, not his class background, nor his material wealth or lack of such, nor his ability or lack of ability to exploit the working classes. ${ }^{76}$ Performed exemplary conduct thus becomes the main qualification for a party member regardless of class background. The concept of biaoxian is central here. Jiang deliberately refers to a concept that stands at the centre of Chinese ideological-political discourse (a point that does not survive in the English translation of the speech) as it connotes a person's moral-political manifestations or outer conduct. Biaoxian is a controllable entity too, and that type of behaviour is even measurable on a point scale. ${ }^{77}$ Biaoxian can also mean to 'show off.' Good biaoxian involves showing off virtue manifesting exemplary views or values, and thus describes a behaviour that contributes to the overall spectacle of virtue. Bad biaoxian is showing off self, disregarding the rules and norms of exemplarity or personal authority. In biaoxian we find the cell of the disciplinary system. Through biaoxian, all kinds of 'little things' come under the surveillance of the exemplary norm, and discipline can be exercised over all types of behaviour. A regime of disciplinary power is established, and the issues of reward and punishment spread into the banalities of every- 
day life. Biaoxian comes very close to what Foucault has termed the 'micro-penalty' of power. ${ }^{78}$ Within such a system the slightest departures from the exemplary norm are open to surveillance because it threatens the prestige structure of the party. It serves as effective organizational cement when spiritual civilization (read exemplarity) is linked to material civilization (read economic management) in a powerful control system. The power of discipline turns productive, so one point about this system is that human energies are channelled in more productive directions, making people calculable and useful at the same time. This is what the corporate view of party admission criteria and the utilization of party cadres is about. It is the usefulness in terms of organizational exemplary and super-social norms that counts, not any social value or norm that might originate in some ideal conception of society. It is attachment to the ideologemes rather than the social norm that matters. The party needs ideology to constantly 'change with the times,' not because it is advanced, but in order to maintain its power.

People in China recognize the falseness and cynicism produced by the biaoxian approach. In a survey asking people to give their opinion about why people applied for party membership, only 4 percent answered: 'They believe in Communism and want to make a contribution.' In total, 59 percent said: 'In reality they want a "party card" which they can use as capital to receive future benefits. ${ }^{179}$ In other words, it is a truism in China that the 'exemplary' way bears a price tag - that of simulation. Even Premier Zhu Rongji admits the problems of bureaucratism and the emerging traits of a culture of deception in his speech at the 9th National People's Congress: 'Formalism and bureaucracy run rife and deception, extravagance and waste are serious in some localities... and with some leading cadres.'He urges officials 'to check bad practices, such as false reports to deceive one's superiors or subordinates. ${ }^{80} \mathrm{Zhu}$, however, simply moralizes over the problem, and urges everyone 'to speak the truth,' failing to see that there is a more structural problem here, that of private rationalities within the organization.

We may talk of structural 'ways of lying' inherent in an exemplary society that force people to behave in prescribed ways, prone to simulating exemplary objective standards. This type of control is different from a control based on shared social norms and values, and represents a counterproductive consequence of exemplarity. Biaoxian is about guaranteeing predictability and smooth running for the party machinery. The possibility for rational calculation and planning on a larger scale runs, however, the risk of being destroyed in the process. The rational- 
ity of the system has a tendency to be reduced to the private calculations of benefit that the system has to offer. The process described serves as a signal of disintegration, a pointer to the internal contradictions of the system and the limits of exemplary control. Outwardly, this simulated behaviour might give the impression of a society resting on unity and stability. An order based on simulation, however, is a superficial one, and the art of ruling loses its power by leaning too heavily on the mechanisms to elicit formal overt obedience.

Underneath the veneer of formal obedience and apparent harmony we discern eruptive conflicts that may suddenly break through the surface in surprisingly violent ways. We have seen recurring peasant uprisings throughout Chinese history. In addition the Cultural Revolution conjures up images of recent disorder still experienced as an ultimate trauma for the present party leadership. At the same time, the many clashes between police and people all over China are seen as a potential and very real threat to the power of the CCP. Waves of conflict are always close at hand in the apparent sea of tranquillity that is China's surface, and there is no reason to think that China's membership in the WTO will lessen that problem.

Jiang's 'xianshi biaoxian' represents a situationalist form of behaviour where the situation defines an individual's action more than inner values do. ${ }^{81}$ Sociologists talk about a 'situated identity' where strict social definitions and forms of conduct make it easier to enhance one's own influence and decide what to do or what to expect another person to do, be it inside or outside an organization. ${ }^{82}$ Situated identity might thus be seen as social maps according to which an individual can orient himself, closely linked to, in our example, the all-embracing ideological 'standards' of conduct. In this sense, the 'standards' are not moral standards, but instrumental standards or standards of situational definition. This might represent a streamlining of the organization and the managerial culture, but again represents the danger of cynicism. It might seem an effective disciplinary and ordering technology, but that technology bites back through its lack of social moorings in a value system. There is another word - biaoyan - that actually describes the process of biaoxian better. Biaoyan means to perform or to act and can stand for performance and exhibition..$^{83}$ 


\section{Ideological Ways of Lying and Erosion From Within}

It is important to emphasize that the exemplary society, and thereby the party, is attacked from within. In fact, exemplary control and order produce their own non-exemplary uncontrollability and disorder. The emergence of private rationalities and lack of predictability is a true paradox of exemplary order. Exemplary control produces the seeds of its own breakdown rather than describing a form of total control. Exemplary society can be regarded as a thin veneer of order only, formalized and paraded to 'hold' a populace that is actually in constant movement, and which does not really see the party as the vanguard of their interests. The party slogan of 'moving with the times' becomes hollow seen in this perspective, as people and party move in different directions.

Organizational simulation suggests a structural lie - and has been described as a situation where one is forced to lie to survive or cope with society or any other type of social or organizational setting for that sake. ${ }^{84}$ This is a defensive type of lying. Religious dissimulation was found among the Reformation Protestants who, far from openly committing themselves to the new faith, dissembled their beliefs by a feigned conformity to Catholicism - a phenomenon called Nicodemism..$^{85}$ In China the practice of feng pai (wind style) is illustrative of simulative action. After the purge of the Gang of Four in 1976, it had already become a rule that one should always lean in the direction of the present political wind whether it was blowing eastward or westward. Far from coping with that problem, Jiang Zemin's managerial party has just continued that tradition.

The biaoxian and simulation of party operators, however, is more about using power than hiding from it. There is a difference between hiding for survival and hiding for opportunity, but both hiding and attacking are part of the daily strategies of the party. The party might be accused of being Orwellian; it probably describes the situation better to call it Machiavellian. In the European tradition, Machiavelli's book The Prince is of course the work on simulation and dissimulation par excellence. ${ }^{86}$ In Chinese culture there is an even richer literature on strategy and deception. ${ }^{87}$ Sunzi's work on the art of war is well known, Han Fei's less so, but more recent books like Li Zongwu's Thick Black Theory [Houheixue], written in 1911, are probably even more important. The book applies well to the existing climate in the party, and it should come as no surprise that this deeply cynical book, banned until 1989, had the Central Party School in Beijing as its leading publisher. Li's theme is: 'When you conceal your will from others, that is thick. When you impose 
your will on others, that is black. ${ }^{188}$ This is the actual performance of the party that fits reality more than the alleged exemplary deeds.

To understand the logic of actual performance, and its inclination towards private rationality within the organization, we need to look briefly at the ideological campaign. The well-organized and well-rehearsed political campaign, the yundong, is the medium through which ideology is propagated. The participants of a campaign can be divided into instigators (shandong) and spectators (kanke), and this categorization might help us understand the internal logic of the campaign. ${ }^{89}$ Some calculate that by playing the role of the instigator they can obtain personal advantage, and perhaps attain prominent political positions as well as economic benefits. These strategists might not be so dominant in numbers, but they form a core of key participants. The spectator is not necessarily a passive onlooker to campaign events, but his or her activities tend to be less calculated and have less of a strategy to them. Enthusiasm for a campaign project is again linked to real existing norms and values. Even if less enthusiasm has been shown for recent campaigns, it is wrong to state that enthusiasm has always been absent from political campaigns. On the contrary, enthusiasm has led to one 'craze' after another. The history of the People's Republic is full of frenzied activities related to ideological campaigns. Somewhat broadly, we might say that a campaign lies between a craze and a career, and the career system was always linked to the 'enthusiasm of the masses.' The career ladder and the party's reward system combined with the cynical attitude towards ideology in itself represents the new opportunity structure of corrupt activities inside the party. The organization and the campaigns are increasingly utilized for private gain. The ideological campaign has brought change, but was always a ladder for career-minded instigators. A campaign represents the time to move up in the organization, and increases the opportunity structure for deception, power and private gain.

Since morality and loyalty lie in the doing, the logic for the instigator to follow is that of any effective bureaucrat. The instigators are the ceremonial masters of overt correct behaviour - the models of super-social norms. Instead of stopping a campaign that does not prove effective, instigators escalate it to reach their own aims. Such inner logic of course may prove highly counterproductive for the organization as a whole. Simulation is thus embedded in a structure of bureaucratic careerism where the parts become more important than the whole, and private rationalities gradually replace the organizational rationality. Without a viable value system at the base, soaring cynicism has replaced the occa- 
sional enthusiasm for ideological campaigns. The element of craze is gone in terms of support for campaign ideas, and party instigators are more and more 'going it alone' without the cheers of campaign spectators. The number of enthusiastic spectators might shrink even further as the new social strata enter the gates of the party, since the new admission criteria are as much about leaving someone out as letting someone in. Opening up to the new social strata in practice means closing the door to groups further down in the social hierarchy.

Rebellion from down below is the dangerous scenario of ideological cynicism. If the party does not deliver in terms of social stability and economic growth, the brittle shell of the organization might instantly snap and break into pieces. The party would probably no longer survive a disaster along the lines of a 1950s Great Leap Forward. Even far smaller steps backwards might be devastating in the present situation, as the party is no longer crisis resistant. It is at the same time immensely powerful and immensely vulnerable. The very mechanisms used to forge and renew the party machine produce its own slag products, and utility might paradoxically turn to breakdown.

Cynicism at the top level produces cynicism throughout the organizational system. One problem is the lack of predictability linked to the party's exemplary norm and the career structure attached to it. This dilemma describes the problematic order of exemplary xianshi biaoxian. You cannot make good decisions unless you can continually monitor their effects. For this you need people who can inform you about the real problems, in particular about the errors of the organization. Such negative feedback, however, is the last thing the leadership is likely to hear about. The bureaucrat or the lay party member will always be afraid of the judgement of higher levels, and whole careers are built on denying error. Lower levels, not being stupid, will routinely sugar-coat the information or just plain lie, delay the truth, or play all kinds of other games with the information. ${ }^{90}$ If people cannot participate directly in making decisions and have no responsibility for them, it is the best strategy to tell the leaders what they want to hear. Every planner needs internal devil's advocates, critics and 'nay-sayers' who have nothing to lose by talking back and opposing the leader. Without such mechanisms, the leader runs the obvious risk of ending up in isolation, in a world of lies, illusions and anachronisms.

Not only do such games prevent predictability, they provide at the same time an ideal climate for corruption. Jiang and his people are aware of the destabilizing effect of corruption within the party, and the con- 
trol aspect of the theory of the 'three representations' is therefore linked to the 'three stresses' (san jiang) campaign, typically focusing more directly on the conduct and the morality of party members. There are explicit warnings here against 'criminals' and 'evil forces' protected by 'connection networks' (guanxiwang) and 'protective umbrellas' (baohu san), linking the problem of corruption to more structural and cultural issues. ${ }^{91}$ There is, however, an overall unwillingness or inability to see the solution to corruption in a more systematic structural and organizational manner. When addressing the problem of private rationalities and corruption, the suggested solutions do not themselves exceed the logic of exemplarity. Everything seems to rest with Jiang's rule of virtue and the morality of the cadres' so-called official virtue (guande). In particular, leading party cadres should possess such official virtue and become exemplary models (biaoshuai) for the masses. ${ }^{92}$ The answer is once more to cultivate the socialist 'new man' in order to prevent evil from happening. ${ }^{93}$

This is of course not addressing the main problem of new opportunity structures and private rationalities which have become new realities of everyday life in the party. The new opportunity structures for corrupt activities are logically enhanced with higher placement in the party hierarchy. The higher the position, the better the opportunity for deception and corruption. The People's Daily, like Premier Zhu, simply prescribes new doses of morality, repeating over and over again the mantra that leaders should set the example and be models in exhibiting good conduct. ${ }^{4}$ The party journal Qiushi, however, stumbles over the real issue. Noting that people in leadership posts have proven to be the most corrupt, the journal correctly blames leading party cadres for the culture of corruption..$^{95}$ Again, no effective checks and balances are suggested, except for urging lower levels to be on the alert and exercise their duties of moral supervision.

\section{Concluding Remarks}

With the memories of their own culture and history in mind, today's ruling elites gradually seem to be losing faith in their own exemplary control system, resorting to more open means of policing the populace. On the surface everything may look calm and stable, but underneath, eruptive resistance and potential breakdown are building up. That the exemplary society is fading and that it produces resistance, however, does not necessarily mean that it will bring about its own demise; that is one just scenario among others. Even if an order built on exemplary norms with increasingly weak social moorings might be a potential time- 
bomb, resistance and rebellion can be halted. Jin Guantao's picture of armed insurrections overthrowing dynasty after dynasty is not likely to repeat itself, says Liu Binyan, suggesting a scenario of disorder where the peasants make use of the weapons of the weak to pillage and sabotage the regime and the cities. ${ }^{96}$ In some ways the Chinese system is highly effective in bringing about order overall. The 'dangerous' fragmentation represented by the modern can be halted by another, 'ordering' fragmentation. Andrew Walder has noted that factionalism and private vendettas were striking features of worker involvement in the Cultural Revolution. He found such personalized struggles to be highly unusual among workers' movements in industrial societies where collective demands are usually made to institutions and groups. Walder looked at the phenomenon from an organizational point of view, stating that 'this personalization of conflict was a direct outgrowth of the system of officially-organized patronage that personalized social control and rewards to an extent unusual in other industrial settings. ${ }^{197}$

Even if the exemplary order is in many ways an inflexible order, the simulation strategies fostered by the system provide flexibility within inflexibility. Private rationalities might destroy the party from within, but private solutions to social problems among the masses might be sought without the mobilization of collective support. Instead of the scenario of breakdown, we witness a scenario of overall order on a background of local conflicts. The system might prove effective, not in keeping exemplary order, but in preventing collective action, easily wiping out local disorder wherever it occurs. In this scenario we see neither the successful utilitarian solution of realistic pragmatism, increased democracy and impartial rule by law, nor the scenarios of total breakdown. Instead we see the continuing power of the party based not on broad social support, but on a repressive system bolstered by social fragmentation. What we might see in China is not so much an exemplary elite serving the people, but rather the strengthening of a lawless elite, looting China in the interests of its members.

Dr. Børge Bakken is a Fellow at the Division of Pacific and Asian History at the Research School of Pacific and Asian Studies, The Australian National University.

\section{Notes}

1 Mark Elvin, 'How Did the Cracks Open? The Origins of the Subversion of China's LateTraditional Culture by the West,' Thesis Eleven, no. 57 (May 1999), pp. 1-16.

2 Ibid., p. 3.

3 Børge Bakken, The Exemplary Society. Human Improvement, Social Control, and the Dangers of Modernity in China (Oxford: Oxford University Press, 2000). 
4 Jiang Zemin, 'Speech at the Meeting Celebrating the 80th Anniversary of the Founding of CPC,' 1 July 2001, Beijing Review, no. 29 (Documents, part two) (19 July 2001), p. i. Hereafter referred to as Jiang Zemin, Speech (part two).

5 Franz Schurmann, Ideology and Organization in Communist China (Berkeley, CA: University of California Press , 1966), p. 105.

6 Li Tieying, 'Makesi zhuyi yao suizhe shidai de fazhan yu er fazhan' [Marxism Should Develop Along With the Times], Qiushi website, www.cass.net.cn/chinese/y/cn.html, 8 February 2002.

7 Karl Marx, Manifesto of the Communist Party, in Samuel Moore's classic translation from 1888, authorized and edited by Friedrich Engels.

8 Schurmann, Ideology and Organization, p. 18.

9 Ibid., pp. 107-8.

10 Ibid., p. 107.

11 Ibid., pp. 108-9.

12 Jiang Zemin, 'Speech at the Meeting Celebrating the 80th Anniversary of the Founding of CPC,' 1 July 2001, Beijing Review, no. 28 (Documents, part one) (12 July 2001), p. xii. Hereafter referred to as Jiang Zemin, Speech (part one).

13 He Baogang, 'In Search of the Mixed Regime: Regime Change and Regime Maintenance in China.' Invited paper presented at the workshop on 'Regime Change and Regime Maintenance in Asia and the Pacific,' the Australian National University, Canberra, 12-13 February 2002, p. 11.

14 For a more thorough discussion on the exemplary society and its norms, see Bakken, The Exemplary Society.

15 Sun Xiting, Jin Xibin and Chen Xiaobin, Jianming jiaoyu xue [Concise Pedagogy] (Beijing: Beijing shifan daxue chubanshe, 1985), p. 231.

16 Qian Mingfang, 'Bangyang jiaoyu xiaoying ruohua de yuanyin yu duice' [The Weakening of the Model Education Effect and Its Countermeasures], Pujiao yanjiu, no. 3 (1990), p. 13.

17 Max Weber, Grundriss der Sozialökonomik, III. Abteilung. Wirtschaft und Gesellschaft, 3. Auflage, (Tübingen: Verlag von J. C. B. Mohr, 1947), p. 140. Translation taken from Weber, The Theory of Social and Economic Organization, trans. A. M. Henderson and Talcott Parsons (New York: Free Press, 1964), pp. 358-59.

18 Ibid., pp. 142-43. English edition, pp. 363-64.

19 Jiang Zemin, Speech (part 1), p. iv. One of China's most distinguished archeologists, Su Bingqi, even claims that 'China's culture is an indigenous one with a tradition of nearly two million years.' See W. J. F. Jenner, 'Race and History in China,' New Left Review, no. 11 (September/October 2001), p. 56.

20 Jin Guantao, Zai lishi de biaoxiang beihou: dui Zhongguo fengjian shehui zhao wending de tansuo [Behind the Phenomenon of History: a Discussion of the UltrastableStructure of the Chinese Feudal Society], (Chengdu: Sichuan renmin chubanshe, 1983).

21 Journal's commentator, 'Yixiang zhongyao dejichujianshe' [Build an Important Foundation], Qiushi, no. 3 (1 February 2001), pp. 49-51.

22 Zhong Xuan, 'Zhengque renshi 'san ge daibiao' de kexue neihan' [Correctly Understand the Scientific Intensions of the 'Three Representations'], Renmin Ribao, 11 September 2001, pp. $1,2$.

23 See Hu Yaobang, 'Create a New Situation in all Fields of Socialist Modernization: Report to the 12th National Congress of the Communist Party of China, 1 September 1982,' Beijing Review, vol. 25, no. 37 (13 September 1982).

24 Jiang Zemin, Speech (part one), pp. viii-ix, xii. Xinhua report, 19 July 2000, quoted in SWB-FE/3898, 21 July 2000, p. G/7.

25 Xinhua report, 20 June 2000, quoted in SWB-FE/3881, 1 July 2000, pp. G/8-10.

26 Xinhua report, 11 July 2001, in BBC Monitoring, 24 July 2001. 
27 Xinhua report, 19 July 2000, quoted in SWB-FE/3898, 21 July 2000, p. G/7.

28 Journal's commentator, Qiushi, no. 3 (1 February 2001), pp. 49-51.

29 Xinhua report, 21 August 2000, quoted in SWB-FE/3927, 24 August 2000, pp. G/4-6 and Xinhua report, 4 December 2000, quoted in SWB-FE/4021, 21 July 2000, pp. G/3-6.

30 Jiang Zemin, Speech (part two), p. v.

31 Christopher Lasch, The Revolt of the Elites and the Betrayal of Democracy (New York: W. W.Norton, 1995).

32 Lu Xueyi (ed.) Dangdai Zhongguo shehui jiezeng yanjiu baogao [Research report on the social stratification in today's China], (Beijing: Shehui kexue wenxian chubanshe, 2002). See figure on p. 9 for an overview of the stratification data.

33 Jiang Zemin, Speech (part one), pp. v-vi.

34 See Anita Chan, China's Workers under Assault. The Exploitation of Labor in a Globalizing Economy. (Armonk, NY/ London: M. E. Sharpe, 2001).

35 Renmin ribao, 16 February 2001, p. 5.

36 X. L. Ding, 'From Big Social Problems to Explosive Political Troubles? The Challenges of Managing a Huge Society under Rapid Transformation at a Politically Difficult Time,' in John Wong and Yongnian Zheng (eds.), China's Post-Jiang Leadership: Challenges and Adaption (Singapore: Singapore University Press, 2002).

37 Data given by China Center for Economic Research, Beijing University in invitation document for the international symposium 'Equity and Social Justice in Transitional China,' Beijing, 11-12 July 2002. For a more detailed discussion on inequality in China and the use of the Gini-coefficient, see the discussion by Chris Bramall, 'The Quality of China's Household IncomeSurveys,' The China Quarterly, no. 167 (September 2000), pp. 689-705, and Carl Riskin, Zhao Renwei and LiShe (eds.), China's Retreat from Equality, Income Distribution and Economic Transition (Armonk, NY/London: M. E. Sharpe, 2001).

38 Zhongguo qingnianbao, 23 December 1999, p. 1.

39 Thomas Rawski, 'What's Happening to China's GDP Statistics?,' China Economic Review, vol. 12, no. 4(2001), pp. 347-54. See also Arthur Waldron, 'China's Economic Facade,' Washington Post, 21 March 2002, p. A35.

40 A scan through the BBC Summary of World Broadcast for just over a year from 2000-2001 revealed violent clashes between civilians and police and military forces involving all kinds of groups, often including thousands of protestors. See SWB-FE/3734, 3738, 3837, 3842, $3896,3903,3908,4017,4026,4031,4077,4099,4102$. Some of the reports commented on several incidents.

41 Some observers tend to see Jiang's admission of broader social strata into the party as an attempt to rebuild the party precisely as a 'national party,' comparing the approach to Sun Ping's earlier call in 1990 for nationalizing the CCP into an 'all people's party' (quanmin dang). See He Baogang, In Search of the Mixed Regime: Regime Change and Regime Maintenance in China, p. 11.

42 Xinhua report, 2 April 2000, quoted in SWB-FE/3814, 4 April 2000, p. G/8.

43 Already in 1990 there were 700,000 party branches in China. The mere size of the organization makes it vulnerable to bureaucratization. See Zhongguo nongye nianjian [China Agricultural Yearbook] (Beijing: Nongye chubanshe, 1991), p. 141. See also He Baogang, In Search of the Mixed Regime,' p. 8.

44 Jiang Zemin, Speech (part 2), p. v.

45 Ibid., pp. v-vi.

46 Qiushi website, www.qsjournal.com.cn, in Chinese, 16 November 2001. See also: Chinese journal on criteria for new party members, BBC Monitoring, 6 December 2001.

47 Jiang Zemin, Speech (part one), pp. xiii-xiv.

48 Renmin Ribao website, 11 October 2001, 'China: Party Daily Commentary Urges Leaders to "Set the Example",' BBC Monitoring, 15 October 2001. 
49 Jiang Zemin, Speech (part two), p. v.

50 Aleksander Zinoviev, The Yawning Heights [Ziiaiushchie vysoty], trans. by Gordon Clough (London: Bodley Head, 1979).

51 Thanks to James Greenbaum for pointing out the connection to me.

52 See Mark Elvin, 'How Did the Cracks Open?,' p. 3.

53 The 'three stresses' campaign is closely linked to the 'three representations,' but focuses more directly on the conduct of the party members. See Xinhua reports 8 November 1999, quoted in SWB-FE/3688, and 10 November 1999, pp. G/9-10.

54 Zheng Hongfan and Chen Yan in a Xinhua report 9 January 2000, quoted in SWB-FE/3734, 11 January 2000, pp. G/4-7.

55 Xinhua report 3 April 2000, quoted in SWB-FE/3814, 4 April 2000, p. G/7.

56 Zhong Xuan, 'Zhengque renshi 'san ge daibiao' de kexueneihan,' Renmin Ribao, 11 September 2001, pp. 1, 2.

57 While only 8 percent of teachers in charge of ideological education cared about political education at all, 27 percent said they had no interest in such education. More than 50 percent paid ritual heed to such education. Li Shuli, 'Cong chongyang diaocha kan wo sheng zhengzhi jiaoshi duiwu' [A Sample Survey Look at the Province's Political Teachers], Zhengzhi jiaoyu, no. 10 (1986), pp. 33-35.

58 These are the very words used to describe the climate in which the recent 'Three Representations' campaign took place. See Xinhua report 2 April 2000, quoted in SWB-FE/ 3814, 4 April 2000, p. G/8.

59 Xinhua report in SWB-FE/3614 16 August 1999, pp. G/8-9.

60 Jiang Zemin, Speech (part one), pp. xiii-xiv.

61 Renmin ribao website 11 October 2001, 'China: Party Daily Commentary Urges Leaders to "Set the Example",' BBC Monitoring, 15 October 2001.

62 Xinhua report in SWB-FE/3688, 10 November 1999, pp. G/7-8

63 Zhenli de zhuiqiu, 11 December 2000, quoted from SWB-FE/4063, 6 February 2001, p. G/6.

64 Xin Bao, Hong Kong, 22 March 2001, p. 27, quoted in SWB-FE/4103, 24 March 2001, pp. G/ 6-9.

65 Schurmann, Ideology and Organization, pp. 106-7.

66 Ibid., p. 107.

67 See for instance the speech by Defence Minister Chi Haotian, quoted by Xinhua, 20 August 2001: 'Chinese Defence Chief Tells Army to Study Jiang's 1 July Speech,' in BBC Monitoring 20 August 2001.

68 See for instance Jiang Zemin, Speech (part 1), p. vii, and Zhu Rongji, website of People's Daily, 6 March 2002, www.english.people.com.cn/ 200203/05/eng20020305_91438.shtml

69 Xinhua report, 27 February 2001, quoted in SWB-FE/4081, 23 February 2001, p. G/7.

70 Cheng Ming, Hong Kong, 1 July 2000, pp. 14/16, quoted in SWB-FE/3918, 14 August 2000, pp. G/3-5.

71 See Zhenli de zhuiqiu, 11 June 2000, quoted in SWB-FE/3925, 22 August 2000, pp. G/8-9.

72 See 'Analysis: Chinese Media in Party Ideology Split,' BBC monitoring research, 30 August 2001, BBC Monitoring, 30 August 2001.

73 Mikhail N. Epstein, After the Future: The Paradoxes of Postmodernismand Contemporary Russian Culture, trans. by Anesa Miller-Pogacar (Amherst: University of Massachusetts Press, 1995), pp. 6, 153-61.

74 Ibid., p. 155.

75 Geremie Barmé has shown how the techniques have spilled over to the opposition, in describing the language and the techniques of debate found among the student leaders at Tienanmen in 1989, most notably that of Chai Ling and her supporters. Geremie R. Barmé, In the Red. On Contemporary Chinese Culture (New York, Columbia University Press, 1999), pp. 326-33. 
76 Jiang Zemin, Speech (part two), pp. v-vi.

77 Børge Bakken, The Exemplary Society, particularly pp. 255-68.

78 Michel Foucault, Discipline and Punish: The Birth of the Prison (New York, Vintage Books, 1979), p. 178.

79 Stanley Rosen, 'Political Education and Student Response: Some Background Factors Behind the 1989 Beijing Demonstrations,' Issues and Studies, no. 10 (1989), p. 19.

80 Website of People's Daily, 6 March 2002, www.english.people.com.cn/ 200203/05/ eng20020305_91438.shtml

81 Francis K. Hsu regards the Chinese as 'situation-centred' in his analysis. From a sociological standpoint, not only Chinese but also Japanese culture can be considered as manifesting a situational ethic as opposed to the more universal ethic built around moral absolutes found in Western Christian thought. See George DeVos, 'The Relation of Guilt towards Parents to Achievement and Arranged Marriage among Japanese,' Psychiatry, vol. 23, no. 2 (1960), p. 288. Of course, one might argue that 'maintaining power at all costs' represent an 'inner value' as well, complicating the text's assumption.

82 Norman C. Alexander and Pat Lauderdale, 'Situated Identities and Social Influence,' Sociometry, vol. 40, no. 3 (1977), pp. 225-33.

83 He Xin, 'Gudu yu tiaozhan: zai hei shehui de bianyuan qu' [Loneliness and Challenge: on the Edge of Black Society], Zixue, no. 3 (1989), p. 16.

84 Perez Zagorin, Ways of Lying (Cambridge, MA: Harvard University Press, 1990).

85 Ibid.

86 Niccoló Machiavelli, The Prince (Toronto: Bantham Books, 1981).

87 See Alastair Iain Johnston, Cultural Realism. Strategic Culture and Grand Strategy in Chinese History (Princeton, NJ, Princeton University Press, 1995).

88 Li Zongwu, Houheixue [Thick Black Theory] Qiushi houheixue, (Hong Kong: Baicheng chubanshe, n.d.), and Houheixue xubian [Thick Black Theory Continued] (Beijing: Tuanjie chubanshe, 1990). For excerpts from the book, see Geremie Barmé and Linda Jaivin (eds.), New Ghosts, Old Dreams (New York: Times Books, 1992) pp. 448-50, and Barmé, In the Red.

89 He Xin, Dongfang de fuxing [The revival of the East], (Heilongiang jiaoyu chubanshe, Heilongjiang renmin chubanshe, Harbin 1991), pp. 285-86. Barmé, In the Red, p. 106, quotes He's first approach towards explaining the campaign mentality in He Xin, 'Zhongguo dangdai beiwanglu. Wode kunhuo yu youlü' [A Contemporary Chinese Cultural Aidemémoire. My Perplexities and Concerns], Jingjixue zhoubao, 8 January 1989, p. 5.

90 See Alvin Toffler, Previews and Premises (London: Pan Books, 1984), p. 97.

91 Xinhua report, 13 December 2000, quoted in SWB-FE/4024, 15 December 2000, pp. G/4-5.

92 Luo Suying, 'Yi dezhi guo zhong zai 'guande' ['Official Virtue' is the Key Link to Ruling the Country by Virtue], Qiushi, no. 12 (16 June 2001), pp. 43-44.

93 Yang Zhonghua, 'Zuo hao 'san jiang' gongzuo peiyu yi dai xinren' [Carry out Work on 'Three Stresses' Well, and foster a Generation of New Men], Qiushi, no. 19 (1 October 2000), pp. 45-47.

94 Renmin ribao, website, 11 October 2001.

95 According to Qiushi; 'Most corruption such as graft and bribery occurs among party-member cadres holding leadership posts; it is not at all easy to get them to supervise themselves, and this requires that the lower-level organizations and party members exercise their duties of supervision as equals within the party,' Qiushi website, Beijing, in Chinese, BBC Monitoring, 16 January 2002.

96 Liu Binyan, 'Another "Rural Encirclement of the Cities" Campaign?,' China Focus, no. 1 (1994), p. 4.

97 Andrew G. Walder, 'Communist Social Structure and Workers' Politics in China,' in Victor C. Falkenheim (ed.), Citizens and Groups in Contemporary China, Michigan monographs in Chinese Studies, no. 56, (Ann Arbor, University of Michigan Press, 1986), p. 84. 